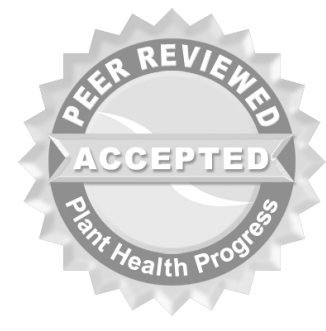

(C) 2013 Plant Management Network.

Accepted for publication 18 December 2012. Published 17 January 2013.

\title{
Coleosporium tussilaginis Found on Senecio nemorensis ssp. fuchsia in Norway
}

Venche Talgø and Halvor B. Gjærum, Bioforsk, Norwegian Institute for Agricultural and Environmental Research, Plant Health and Plant Protection Division, Høgskoleveien 7, 1432 Ås, Norway; and Ole B. Hansen, Norwegian University of Life Sciences, Department of Plant and Environmental Sciences, Postboks 5003, 1432 Ås, Norway

Corresponding author: Venche Talgø. venche.talgo@bioforsk.no

Talgø, V., Gjærum, H. B., and Hansen, Ole B. 2013. Coleosporium tussilaginis found on Senecio nemorensis ssp. fuchsia in Norway. Online. Plant Health Progress doi: 10.1094/PHP-2013-117-01-BR.

The heteroecious rust fungus Coleosporium tussilaginis (Pers.) Lév. occurs on several genera of Asteraceae in many countries in Europe and also in the other continents. It embraces many specialized forms (f. sp.), often described as species in the literature. This situation is reflected in Index Fungorum (3), where 44 synonyms and $9 \mathrm{f}$. sp. of the fungus are listed. C. tussilaginis is host alternating with many species of pine (Pinus spp.) $(1,5)$.

In 2008, symptoms caused by C. tussilaginis were observed in an ornamental planting of alpine ragwort [(Senecio nemorensis L. ssp. fuchsia (C. C. G mel) Čelak] in Enningdal, Halden (Østfold Co.), Norway. Figure 1 shows development of the infected plants throughout the 2010 growing season. The infection started on the lowermost leaves of each plant in June and spread rapidly upwards during mid-summer. The aesthetic value was clearly reduced by August. Infected leaves developed chlorotic and necrotic spots, and the lower surfaces of diseased leaves soon became covered with orange uredinia and yellowish urediniospores (Fig 2). The planting had been established in spring 2007 by apparently healthy plants. The plants had been vegetatively propagated from stock plants that had thrived in the municipality of Ås in the neighboring Akershus Co. for a long period after being imported from a German ornamental nursery. Transplants from the same origin as the plants in Enningdal were also planted at a new location in Ås in 2007, with neighboring pine trees. Both stock plants and transplants were still disease free in Âs in 2012.

In June 2010, aecidia were found on needles from Scots pine (Pinus sylvestris L.) next to the diseased S. nemorensis (Fig. 3). In October the same year, the rust was found on common groundsel (S. vulgaris L.) in the vicinity of a $S$. nemorensis planting (Fig. 4). The fact that $S$. nemorensis plants from the same origin planted in other locations were healthy may indicate that the $S$. nemorensis plants in Enningdal were infected from $S$. vulgaris, possibly via Scots pine. However, according to Gäumann (1) C. senecionis (Pers.) Fr. [one of the syn. of C. tussilaginis (3)], occurs in at least four f. sp. The one on $S$.

nemorensis ssp. fuchsia is f. sp. senecionis nemorensis Fischer while the one on $S$. vulgaris is f. sp. senecionis silvatici Wagner. Only the latter is now recognized as f. sp. (3). Therefore, based on available literature, nothing certain can be said about origin of the present fungus.

The urediniospores from $S$. nemorensis were globoid or ellipsoid, measured 24.2-(29.3)-35.0 × 15.8-(19.0)-22.1 $\mu \mathrm{m}(\mathrm{n}=25)$, and had hyaline, densely verrucose, 1-1.5 $\mu \mathrm{m}$ thick walls (Fig. 2). The urediniospores from $S$. vulgaris were morphological identical to the ones from $S$. nemorensis. The aeciospores from the pine needles were ellipsoid or somewhat angular, measured 20.4(25.1)-30.0 × 17.2-(21.4)-24.0 $\mu \mathrm{m}(\mathrm{n}=25)$, and had verrucose, 1.5-2 $\mu \mathrm{m}$ thick walls (Fig. 3). 


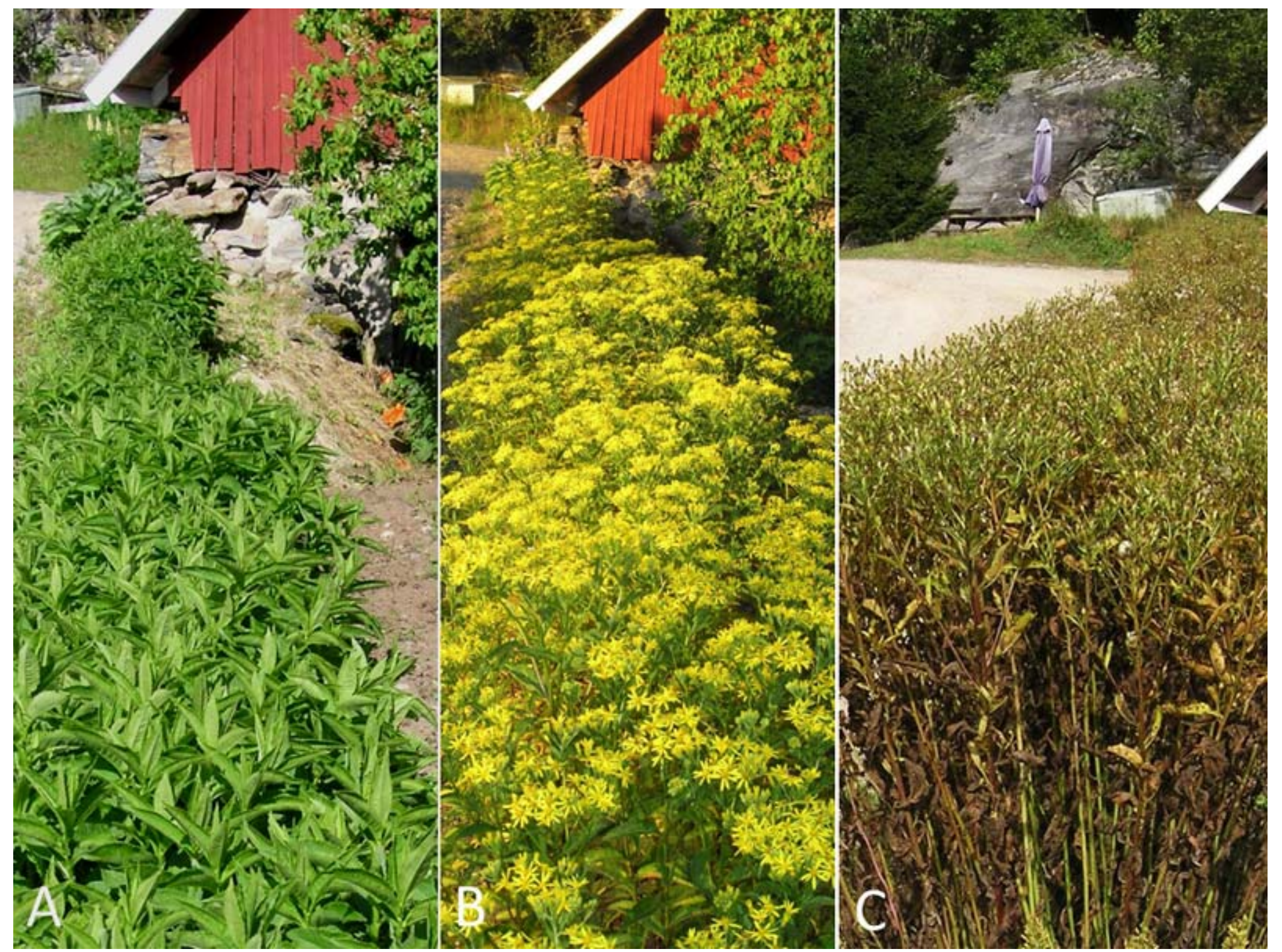

Fig. 1. Alpine ragwort (Senecio nemorensis ssp. fuchsia) in Enningdal in Østfold Co., 2010: (A) June 20th; (B) July 28th; and (C) August 23rd. The plants were infected by Coleosporium tussilaginis, and were severely damaged by August. Photos: Ole Billing Hansen. 


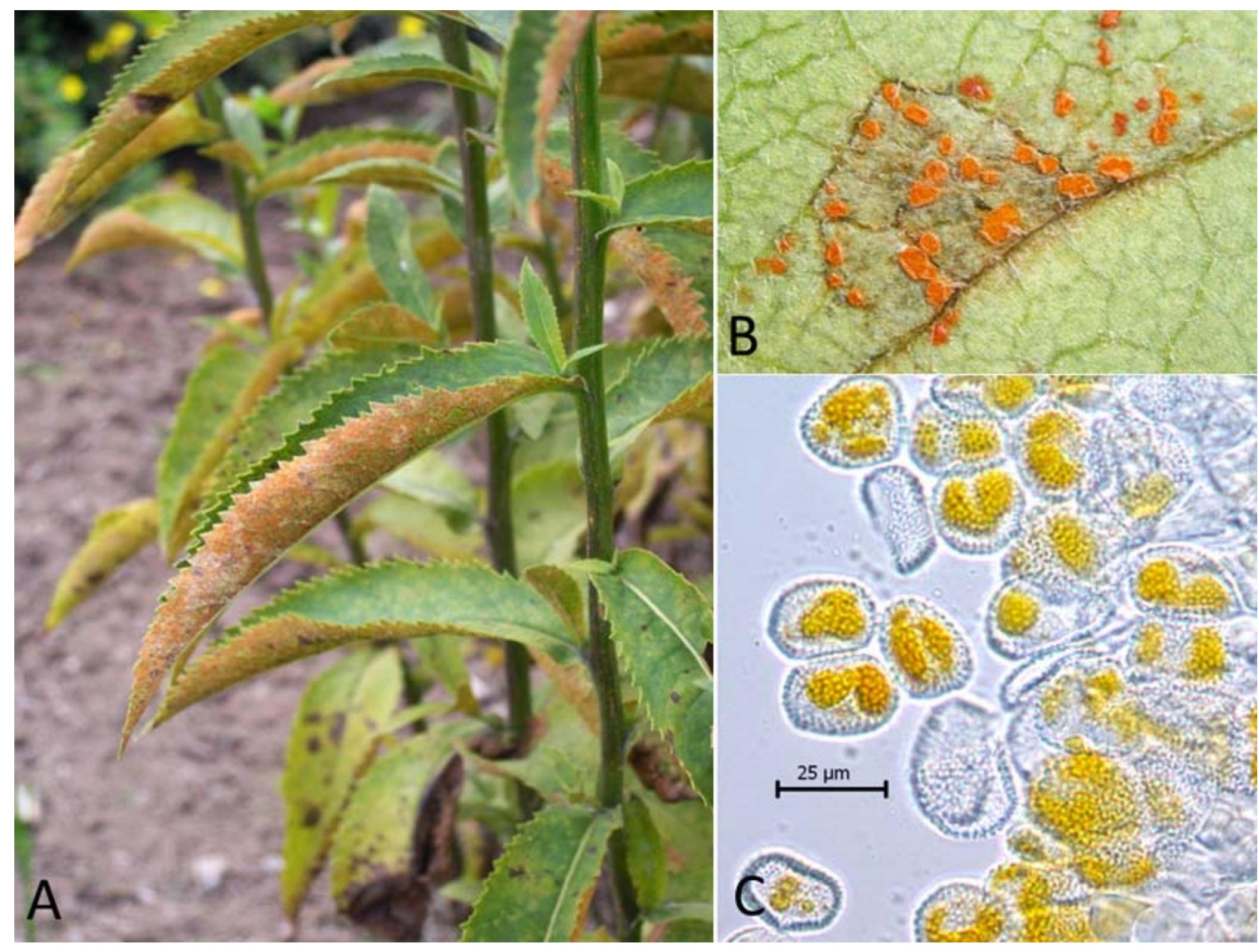

Fig. 2. Coleosporium tussilaginis on alpine ragwort (Senecio nemorensis ssp. fuchsia): (A) chlorotic and necrotic spots on upper leaf surfaces, and uredinia on lower leaf surfaces (August 8th 2010); (B) uredinia; and (C) urediniospores (scale bar = $25 \mu \mathrm{m}$ ). Photos: Ole Billing Hansen (A) and Venche Talgø (B, C). 

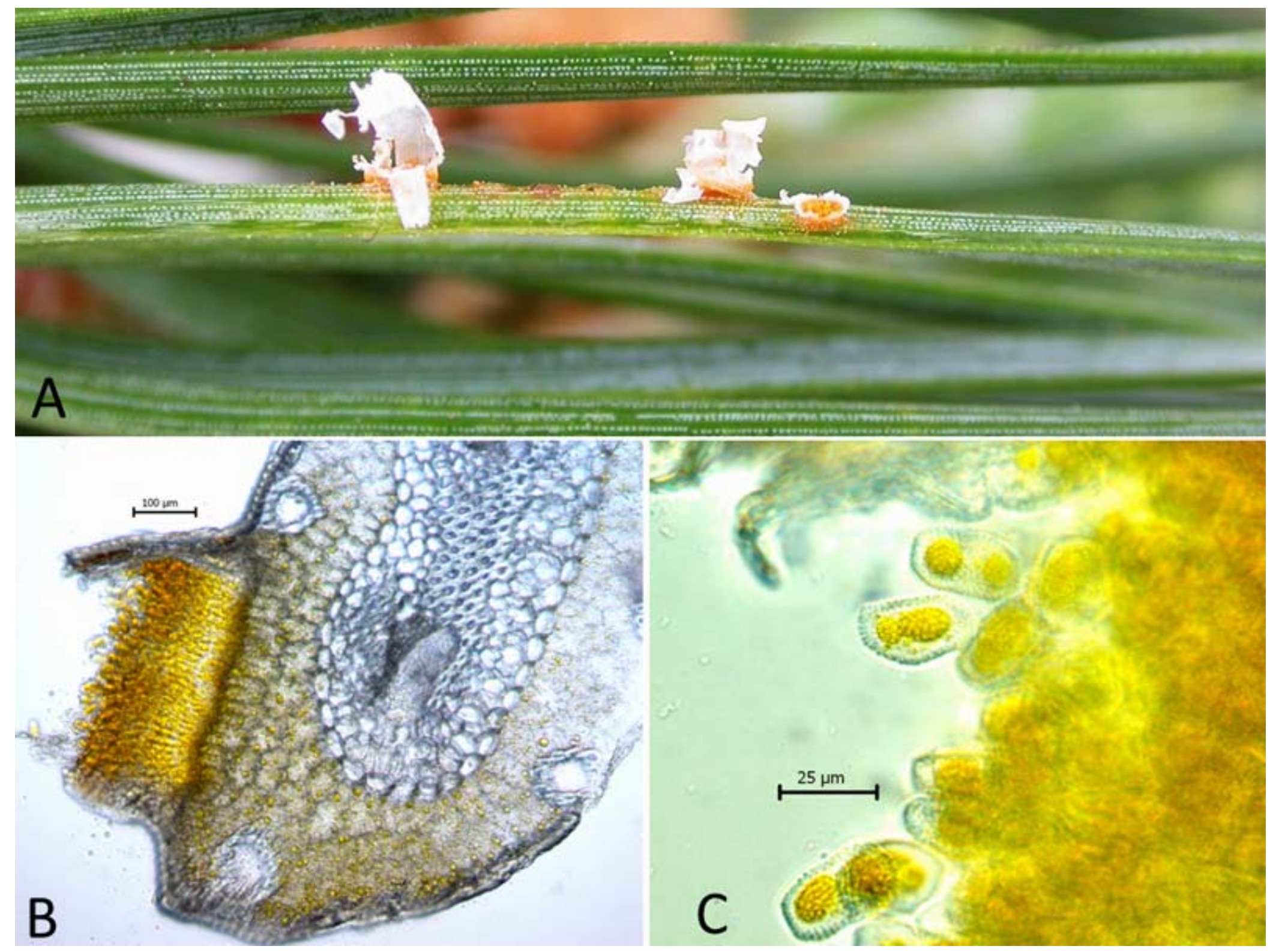

Fig. 3. Coleosporium tussilaginis on Scots pine (Pinus sy/vestris); (A) Aecia with aeciospores surrounded by white peridia, (B) transverse section of a pine needle with an aecidium (scale bar $=100 \mu \mathrm{m})$, and $(\mathbf{C})$ aeciospores (scale bar $=25 \mu \mathrm{m})$. Photos: Venche Talg $\varnothing$. 


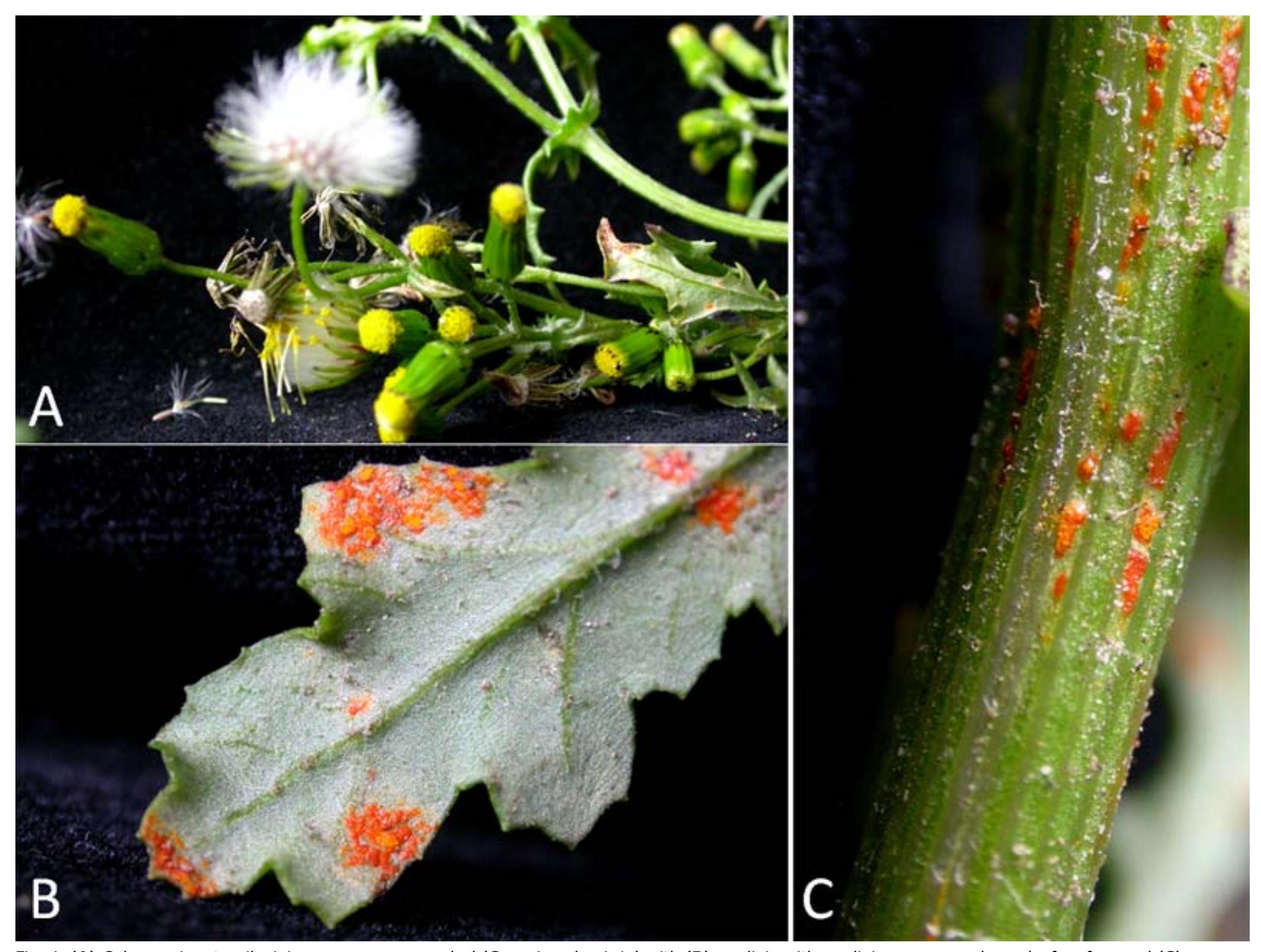

Fig. 4. (A) Coleosporium tussilaginis on common groundsel (Senecio vulgaris L.) with (B) uredinia with urediniospores on a lower leaf surface and (C) on a stem. Photos: Venche Talgø. 
Although C. tussilaginis is reported on $S$. nemorensis from many European countries, from France in the west (2) to Russia in the east (4), this is the first report of the fungus on this plant species in Norway.

Acknowledgments

We acknowledge Mr. Jafar Razzaghian at Bioforsk for valuable technical assistance.

\section{Literature Cited}

1. Gäumann, E. 1959. Die Rostpilze Mitteleuropas mit besonderen Berüchsichtigung der Schweiz. Buchdruckerei Bühler and Co., Bern, Switzerland.

2. Guyot, A. L., and Massenot, M. 1958. Contribution à l'etude des Uredinees de l'Est de la France. I. Uredineana 5:415-460.

3. Index Fungorum. 2012. Online. CABI Bioscience, Wallingford, England, UK.

4. Kuprevich, V. F., and Ul'janishchev, V. J. 1975. Opredelitelj rchavchinnych gribov SSSR. Minsk, Belarus.

5. Wilson, M., and Henderson, D. M. 1966. British Rust Fungi. Cambridge Univ. Press, Cambridge, UK. 